\title{
伊勢湾における海況変動とプランクトン分布についで*
}

故 赤塚三㐋 ${ }^{* *}$ 上野福三** • 三谷勝次 ${ }^{* *}$ ・宮村光武***

\section{On the Relation Between the Distribution of Plankton and the Annual Changes of Sea Condition in Ise Bay.}

\author{
The late Kozo Akatsuka, Fukuzo Uyeno, \\ Katsuji Mitani and Mitsutake MiYamura
}

\begin{abstract}
This report deals with a relation between the seasonal changes of plankton and the sea conditions in Ise Bay based on the observations 'covering- from Oct., 1950 to Dec., 1951.

In Ise Bay less haline water which is !affected by land drainages extends to southward from innermost part of the bay along the west coast, while haline water invades northward from the entrance to the eastern part of the bay. Distribution of both waters is shown by the horizontal distribution of chlorinity in the surface. The borders of both waters are usually found near the isohaline lines of 15 and $17 \mathrm{Cl} \%$ namely horizontal gradients of surface chlorinity becomes steep near the both isohaline lines in every month. The extentions of the waters are represented by the location of both isohaline lines in the bay. Distributions of phytoplankton have intimate relation with the one of chlorinity; accordingly, most abundant regions of various species appear separately in three regions - more than $17 \mathrm{Cl} \%$, $15-17 \mathrm{Cl} \%$ and less than $15 \mathrm{Cl} \%$ — according to their responses for chlorinity. This division corresponds to following three groups in annual changes of phytoplankton appearrance: 1) Oceanic group. The species belonging to this group occur in most haline seasons at the sea area near the entrance of the bay. 2) Neritic group I. Main populations are found in the innermost part of the bay in haline seasons and in the sea near the entrance in less haline seasons. 3) Neritic group II. Usually appears near the innermost part of the bay. In some stenothermal species, however, the distributions are affected by the changes of temperature.

In zooplankton, eury-haline neritic species and larvae of coastal benthic animals are dominant, because of extreme less haline of the water. Oceanic 'species appears only here and there in the invading water in most haline months from Oct. to Dec.
\end{abstract}

\section{1. 緒 贯}

伊勢湾の海洋調査については, 三重県ならびに 愛知県水産試験場により古くからなされてきた。 しかしながらプランクトンを含む総合的海洋観測 の解析が行なわれた例は少なく, 1929 年 11〜12 月に海洋気象台 (海洋気象台, 1933) ${ }^{1}$ により実施

$* 1960$ 年 4 月 19 日受理

三重県水産試験場伊勢浮分場 業績第 9 号

**三重県立大学水産学部 Faculty of Fisheries, Prefectural University of Mie.

*** 三重県水産試験場伊勢湾分場 Ise-wan Branch, Fisheries Experimental Station of Mie Prefecture.
されたものをみるだけである。したがつて伊勢湾 の海況の周年变動とプランクトンの季節变動との 関係について解析したものは全くなかつた。

三重県水産試験場伊勢湾分場では本湾のイワシ 資源調査の目的をもつて行なつている観測の一環 としてプランクトン調查を 1950 年 10 月より 1951 年 12 月まで実施した。ここに解析したもの はこの資料に基ずくものである。

調査海域は伊勢湾口から湾奥に至る湾全域で, 観測点は約 60 設定してあるが，各観測時毎に多 少の移動がある。観測日の間隔は括括むね 1 ケ月 で，各月下旬に行なわれている。1951 年 1, 2, 
9 月の各観測時は湾奥だけである。また四日市一 日長線以北の湾奥部と以南の中, 南部々は各観測 時とも観測実施期日に数日のずれがある。なお, プランクトン以外の各観測結果は事業報告（三重 県水産試験場伊勢湾分場, 1950, 1951)2) としてす でに出版されている。

試料の採集は持ネット(径 $45 \mathrm{~cm}, \mathrm{XX} 13$ 番 網地使用）を用いて底層より表面までの鉛直採集 を行ない, フォルマリン固定後検鏡した。プラン クトン量は, 動植物全量に対して RC 法により表 現した。検鏡は採集直後故赤塚孝三によりなさ れ, その後解析がされないまま宮村光武により保 存されていた資料を, 今回上野福三, 三谷勝次が 取りまとめ, 海況との関連性を解析したものであ る。したがつてプランクトンの絶体量と海況との 関係については解析することができず，単に相対 的な関係だけを示した。また 1951 年 $5 ， 6$ 月の 動物プランクトン資料が失なわれている。

計数されたプランクトン種数は植物プランクト ン 240 種, 動物プランクトン 190 種に拉よび, 沿 岸性, 外洋性または冷水性, 暖海性のほとんど全 般にわたるが，散発的に出現した種が多い。これ らの中より定常的に出現したり，広範囲にわたつ て分布するものを植物プランクトン (Dinoflagellata を含む) 中ょり 58 種, 動物プランクトン より 21 種選択し, これらの出現傾向を解析して 表層の水温，塩素量の分布を対比させた。

\section{2, 海況概要}

一般にプランクトンの消長，ならびに分布は海 況に対応する。本報に用いられた資料と同時に観 測された水温, 塩素量より海況の概要を述べる。

一般に伊勢湾のように湾口が狭く，かつ大河川 を有する湾では，河川からの流入水が海況に括よ ぼす影響は，はなはだ大きく，当湾でも三大河川 （木曾, 揖斐, 長良川）の流入水が大きく関係し, さらに遠州灘北部を西に流れる黒潮反流が関与し て, それらの勢力の消長によつて海況に著しい差 を生ずる。

すなわち, 塩素量 $(0 \mathrm{~m})$ (Fig. 1) についてみ ると，もつとも低かんとなる 7 月を頂点として 6 〜 月汭けて湾奥部と湾口部には著しい差を生

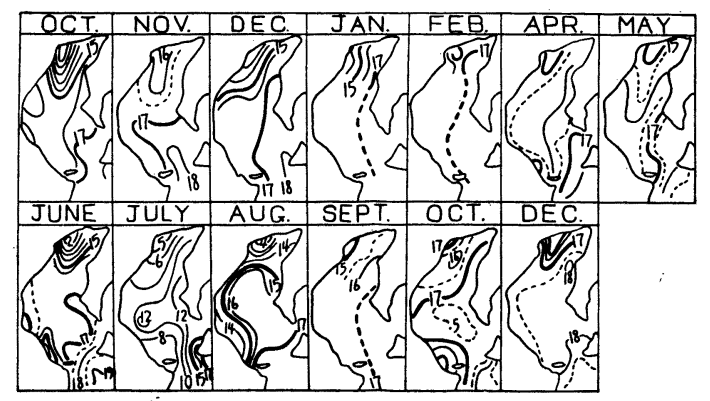

Fig. 1. Distributions of surface chlorinity $(\mathrm{Cl} \%)$ in Ise Bay from Oct., 1950 to Dec., 1951.

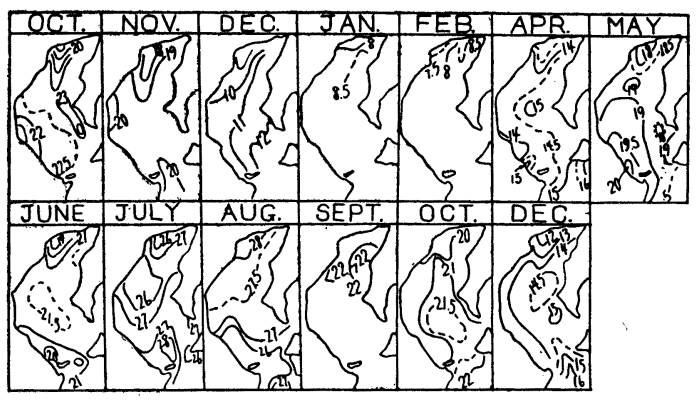

Fig. 2. Distributions of surface temperature $\left({ }^{\circ} \mathrm{C}\right)$ in Ise Bay from Oct., 1950 to Dec., 1951.

じまた流入河川水の量が少なくなる 11 月〜翌 2 月にかけては湾口からの外洋水の侵入が皃とん ぞ湾奥に及び，湾内の全域を高かんとする。また 水温 $(0 \mathrm{~m})($ Fig. 2) については, 冬季には湾奥 部が低く，湾口部が高くなり，夏季にはそれと反 対の現象がみられる。表層の最低水温は 2 月湾奥 で $7^{\circ} \mathrm{C}$ 前後を示し, 最高水温は 2 月湾奥及び大 湊沖停滞部で $28^{\circ} \mathrm{C}$ を示している。

一般に伊勢湾の環流は, 木曾, 長良, 揖斐の三 大河川流入水が西部沿岸を南下し, 黒潮反流は三 河湾の影響を受けながら東部沿岸に沿つて北進す る傾向がみられ，中央部付近に大きな停滞部を形 成する。Fig. 1 は表層の塩素量分布の季節 的変 動を示しているが，これにより侵入外洋水と流入 河川水の季節的消長が明瞭に示される。すなわ ち, $15 \mathrm{Cl} \%, 17 \mathrm{Cl} \%$ の等塩素量線付近は常にそ の水平傾度が急で, $15 \mathrm{Cl} \%$ の線をもつて流入河 川水の影響域を， $17 \mathrm{Cl} \%$ の線により侵入外洋水 の影響域の境界線をそれぞれ概略的に知ることが 
可能である。これによると河川流入水量の著しい 7 月に扣いては, $15 \mathrm{Cl} \%$ の等量線は湾口まで押 し下げられ, 湾内は著しく低かんとなり, 最低值 は湾奥では $2 \mathrm{Cl} \%$ に達する。 8 月にはその傾向 が徐々に回復し，9〜12 月に至つては湾口からの 侵大外洋水の勢力が大となり, 1951 年 12 月に は $17 \mathrm{Cl} \%$ の等量線が湾奥付近に達し, 湾内 の ほぼ全域が $17 \mathrm{Cl} \%$ 以上となつている。1，2月 も降雨少なく, 侵入外洋水は東部沿岸に沿つてほ とんど湾奥にまで達し, かなり湾内は高かんとな る。しかしながら 4, 5 月に至ると, 湾奥部 15 $\mathrm{Cl} \%$ ，湾口部 $18 \mathrm{Cl} \%$ となり，その傾度はゆる やかとなるが， $17 \mathrm{Cl} \%$ の等塩素量線は湾口付近 まで押し下げられる。6 月に入ると, 梅雨期の降 雨の影響が現われて, 湾奥部は著しく低かんとな るが，その勢力は侵入外洋水を湾口まで押し出す には拉よばず, 傾度が湾奥付近に打いて極度に急 となつて，湾の中央部は $16.5 \mathrm{Cl} \%$ 前後を示す。 また $17 \mathrm{Cl} \%$ の等量線は前月に比し幾分三河湾方 面に押し出されているにすぎない。

以上を概説すると，本湾は当然のことながら内 湾的傾向が強い。ただ, 表層水温の周年变動域は 大阪湾, 東京湾などと大差はないが, 塩素量值の 上下差は極度に大きく, 上記等の本州南岸付近の 内湾とは比較にならない。

\section{3. 植物プランクトン}

前述のよ5に, 本湾は内湾的傾向が強く, その 塩素量変動は極度に大であるため, プランクトン 分布もほとんど塩素量值の変動に応じて分布して いるに近い。特に本湾の水温, 塩素量に対する特 性図 (上野, 1959) 31 の中心付近に位置し, 特定の 狭温種以外の多くの内湾種は, その量特性がほと んど塩素量と逆相関関係を持つている。したがつ て, 一般の内湾種と異なり $17 \mathrm{Cl} \% 0$ 付近の低かん 域が占める面積が大きく, 各種の分布特性も内湾 種, 外洋種だけでなく, 内湾種の中でも特に低か 几な水域に分布の中心があるものと, 比較的高い ところに中心のあるものとの差が明確に分れる。 したがつて本稿では, 表層の塩素量变動をもつて 流入陸水ならびに侵入外洋水の動勢を代表させ, これと珠藻分布との関係をみた。
一般的にいつて, 内湾種で比較的低かんを好を ものが湾奥から西岸一帯にかけて分布し, 内湾種 でありながら外洋的性格の強いもの, 拉よび純外 洋種が湾口からの黒潮反流の流入の程度に応じて 出現しているのが顕著にわかる。

出現した主要種を分布上の傾向から大別する と,つぎの 3 グループに分類することができる。

1）比較的高かんな外洋水侵入水带に扣もに出 現するもの。

2）高かん期には低かんな湾奥に，低かん期に は西部または湾口に分布の中心が移動するもの。

3）低かんな三大河川流入水带に扮もに出現す るもの。

I 外洋水帯に扮もに出現する種について

7〜12 月, 外洋水の侵入群を中心として出現す る比較的外洋性の強い内湾種执よび外洋種である が，8〜12 月の最高かん期にだけ出現のみられる ものと，周年みられるものとに分れる。前者は好 適域が最も高かん部であるため, このように出現 期が制限されたものと考兄られ, 多少内湾種もま ざるが，ほとんど，いわゆる外洋種である。これ に対し, 後者は内湾的傾向が強く, 細胞数も極度 に多いものがあり，大部分内湾種である。一部混 入している外洋種は最低かんの 5 〜月にはみら れない。この 2 群中, 前者については水温の影響 を受けて出現期が限られたとみるものを区別する ことは不可能であるが, 後者中には Biddulphia sinensis, Coscinodiscus rothii 㧊よび Chaetoceros compressus が冬季 $1 \sim 3$ 月に出現”せず, 8 月に著しく多い。これは水温の影響によるもの と考学られる。このほか外洋的性格が強いうえに 水温に左右されて出現期が短期間のものがある。 このようなものには冷水種で冬季現われるChaetoceros decipiens および Ch. densus と熱帯性 で夏季だけにみられる Clymacodium frauenfeldianum 执よび Cl. biconcavum の 2 種がある。

このような出現傾向別に各種を分類すると Table 1-(1) に示すようになる。

高かん期に侵入乙, 外洋水域を中心として出現 する群の 5 ち，代表的傾向を示す Rhizosolenia calcar-avis について分布の周年変化を Fig. 3 に 示した。この種は最も外洋性強く, かつ暖海性の 
Table 1. Dominant Phytoplankton Species in Ise Bay from Oct., 1950 to Dec., 1951.

1) The species occurred in relatively haline region.

\begin{tabular}{|c|c|c|}
\hline Occurred over the entire periods. & $\begin{array}{l}\text { Occurred only in most } \\
\text { haline season }\end{array}$ & $\begin{array}{l}\text { Occurred in special restricted } \\
\text { seasons. }\end{array}$ \\
\hline $\begin{array}{l}\text { Biddulphia longicruris } \\
\text { Chaetoceros eibenii } \\
\text { C. didymus } \\
\text { Coscinodiscus janischii } \\
\text { Guinardia flaccida } \\
\text { Rhizosolenia alata f. gracillima } \\
\text { R. robusta (exc. May to July) } \\
\text { R. setigera } \\
\text { R. stolterfothii } \\
\text { Thalassiothrix frauenfeldii } \\
\quad \text { (exc. May and June) } \\
\text { Biddulphia sinensis (absent in winter) } \\
\text { Chaetoceros compressus } \\
\quad \text { (absent in winter) } \\
\text { Coscinodiscus rothii (absent in winter) }\end{array}$ & $\begin{array}{l}\text { Biddulphia mobiliensis } \\
\text { Chaetoceros coarctatus } \\
\text { C. peruvianus } \\
\text { C. curvisetus } \\
\text { C. lorenzianus } \\
\text { Corethron hystrix } \\
\text { Coscinodiscus concinus } \\
\text { Hemiaulus hauckii } \\
\text { Lauderia borealis } \\
\text { Rhizosolenia calcar avis } \\
\text { Thalassiosira subtilis } \\
\text { Ceratium furca } \\
\text { C. fusus } \\
\text { C. pennatum }\end{array}$ & $\begin{array}{l}\text { Winter to spring: } \\
\text { Chaetoceros decipiens } \\
\text { C. densus } \\
\text { Summer: } \\
\text { Clymacodium frauenfeldianum } \\
\text { C. biconcavum }\end{array}$ \\
\hline
\end{tabular}

2) The species near the boader between neritic water and invaded water.

\begin{tabular}{|c|c|}
\hline $\begin{array}{l}\text { Occurred over the } \\
\text { entire periods. }\end{array}$ & $\begin{array}{l}\text { Occurred in special } \\
\text { restricted seasons. }\end{array}$ \\
\hline Actinoptychus undulatus & Summer: \\
\hline Ditylum brightwellii & Chaetoceros \\
\hline Eucampia zoodiacus & laciniosus \\
\hline Guinardia flaccida & Autumn: \\
\hline $\begin{array}{l}\text { Stephanopyxis } \\
\text { palmeriana }\end{array}$ & $\begin{array}{l}\text { Dinophysis homunculus } \\
\text { Peridinium pennatum }\end{array}$ \\
\hline Nitzschia seriata & Ceratium bergonii \\
\hline Ceratium tripos & \\
\hline C. macroceros & \\
\hline C. intermedium & \\
\hline
\end{tabular}

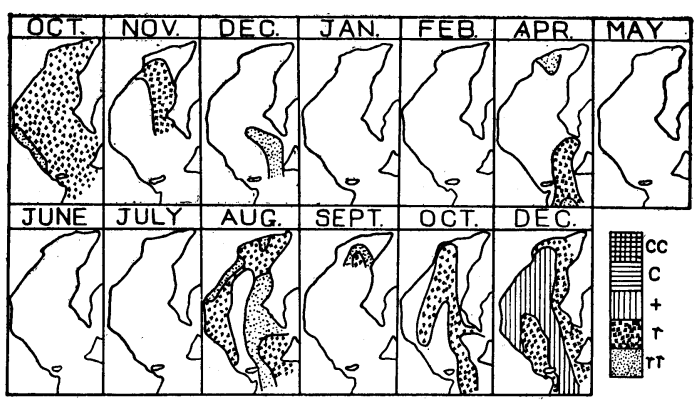

Fig. 3. Distributions of Rhizosolenia calcar avis in Ise Bay from Oct., 1950 to Dec., 1951.
3) The species occurred in relatively less haline region.

\begin{tabular}{l|c}
\hline \hline $\begin{array}{c}\text { Almost independent } \\
\text { to the changes of } \\
\text { temperature. }\end{array}$ & $\begin{array}{c}\text { Abundant in special } \\
\text { restricted seasons. }\end{array}$ \\
\hline $\begin{array}{c}\text { Skeletonema costatum } \\
\text { Thalassionema } \\
\text { nitzschioides }\end{array}$ & $\begin{array}{c}\text { Summer: } \\
\text { Bacteriastrum } \\
\text { varians }\end{array}$ \\
Peridinium conicum & Chaetoceros affinis \\
$P$. pallidum & C. diversus \\
Gonyaulvx polygramma & Winter: \\
& Chaetoceros socialis \\
& C. subsecundus \\
\hline
\end{tabular}

ため 8〜12 月の高かん期に侵入水帯に多く，最 も高かんとなつた 1951 年 12 月が最も多い。1 〜 月の低温期には出現がみられず，4 月にわず かに湾口付近にみられる。

つぎに多少内湾性を括びるため周年出現してい るグループの例として Fig. 4 に Biddulphia longicruris の分布を示した。これょり全期間中 の出現変動をみるとつぎのようになる。1950 年 10 月には湾口から多量の侵入があり，全域に分 布したが，特に外洋水侵入路に多い。同年 11 月 全域に多く分布しているが，量の地域差は前月よ 


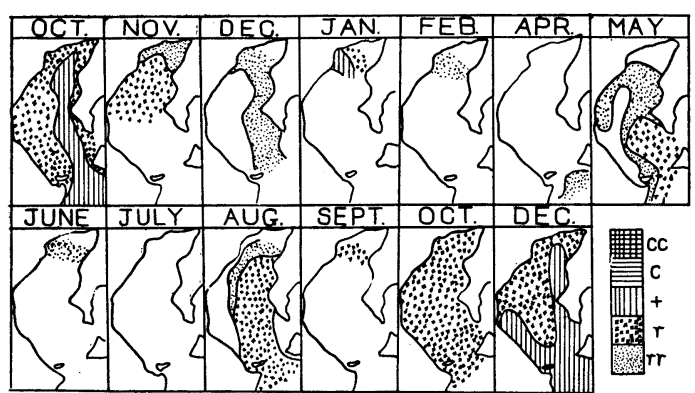

Fig. 4. Distributions of Biddulphia longicruris in Ise Bay from Oct., 1950 to Dec., 1951.

り小さくなつている。12月には河川からの流入水 がみられたため外洋水侵入路に分布し，西部には 出現しなくなつた。これが 1951 年 1 月になり河 川流入水の停止とともに西部に増加し，2月には 前年11月と同様全域に広がつた。しかしながら, 4 月には河川流入水の増加からふたたび湾口付近 だけに分布し $, 5,6$ 月には外洋水の侵入があつた ため,わずかながら中央部まで進んでいる。7 月 には梅雨期の降水により湾内の塩素量が著しく低 下したため出現せず，8 月になつて湾内の塩素量 が回復して $15 \mathrm{Cl} \%$ の当量線が湾内深くまで入り こんだのに伴つて中央部まで進出している。これ 以後 9 月には,さらに湾奥まで侵入して 10 月に 至り全域に分布を拡大したが，12 月にはますま す增加して湾奥付近には著しく多くなつている。

な括 Dinoflagellata では, 一般に内湾性の強 い Ceratium furca, C. fusus, C. pennatum る, 本湾では比較的高か九水域に出現がみられ, かつ出現期が秋季であるため Table 1 では最高 かん群に入つているが，これらの種がはたして高 かん域を好むかどうかについてはな揟問があ る。

II 高かん期には低かんな湾奥に，低かん期に は西部または湾口に分布の中心が移動するも の。

これらのグループは前グループに比べて分布域 が上下とも狭く, $16 \mathrm{Cl} \%$ 前後で高かん期には湾奥 に分布し, 低かん期には西部方面に周年出現して いる, Actinoptychus undulatus(Fig. 5), Stephanopyxis palmeriana, Eucampia zoodiacus, Ceratium intermedium, Nitzschia seriat.があり,

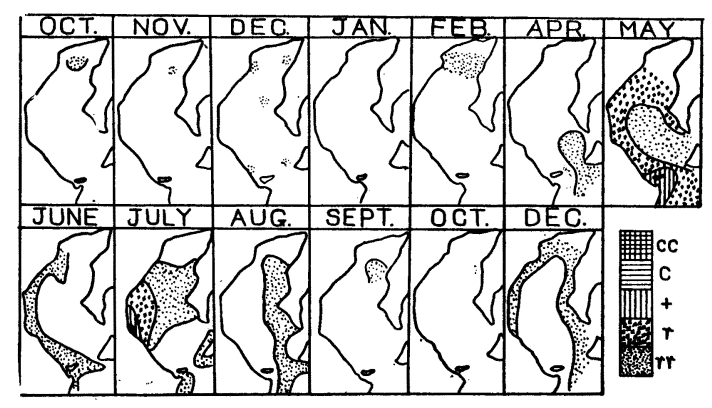

Fig. 5. Distributions of Actinoptychus undulatus in Ise Bay from Oct., 1950 to Dec., 1951.

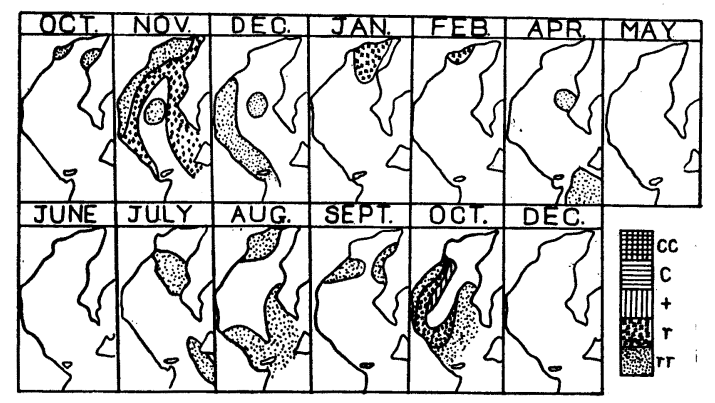

Fig. 6. Distributions of Ceratium tripos in Ise Bay from Oct., 1950 to Dec., 1951.

N. seriata は三河湾の影響も受けて当海区に 9 12月に多く現われている。またDinoflagellata の Ceratium tripos (Fig. 6), C. macroceros, Diatom の Ditylum brightwellii 等も5, 6 月は出 現しないがほぼ同傾向を示している。

低温となる冬季を除き, 比較的高温期（ 7 ～12 月）に招もに湾奥に出現するものとして Dinophysis homunculus f. pedunculatus, Peridinium pennatum, Ceratium bergonii などがあり, Chaetoceros laciniosus もほぼ同傾向を示してい る。以上本群の出現傾向をまとめると Table 1(2)のようになる。

III 低かんな三大河川流入水帯に扣もに出現す るもの。

周年出現する最も主要な暖海性内湾 種である Chaetoceros affinis は主として 8〜9 月に多く出 現し， $17.5 \mathrm{Cl} \%$ 以上の高かん期には少なく, ま た低温時には比較的高温な湾口の方が多くなる。 このような傾向は大阪湾にるみられる(上野, 1957) ${ }^{4)}$ 。さらに本湾に周年顕著にみられるものと 


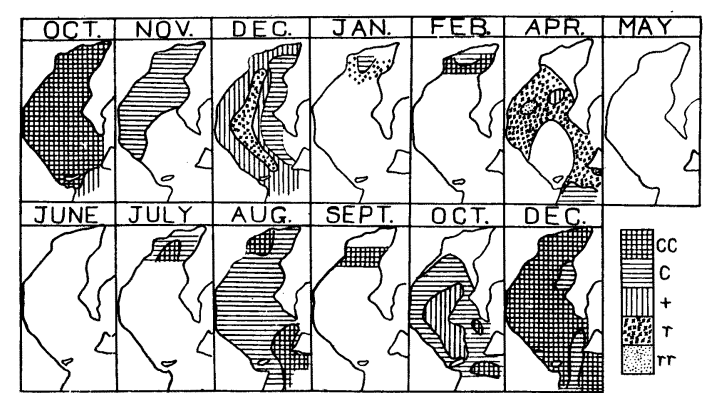

Fig. 7. Distributions of Thalassionema nitzschioides in Ise Bay from Oct., 1950 to Dec., 1951.

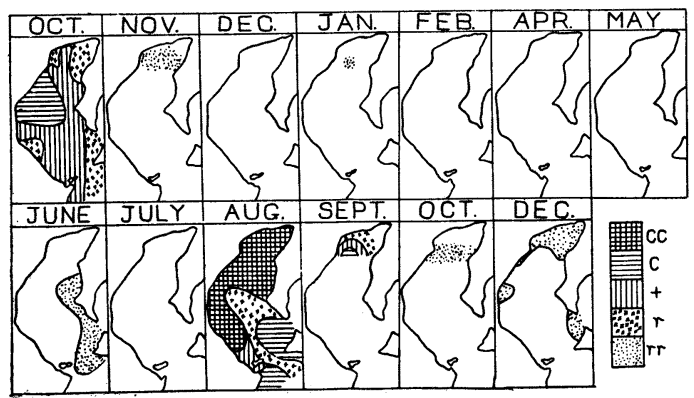

Fig. 8. Distributions of Bacteriastrum varians in Ise Bay from Oct., 1950 to Dec., 1951.

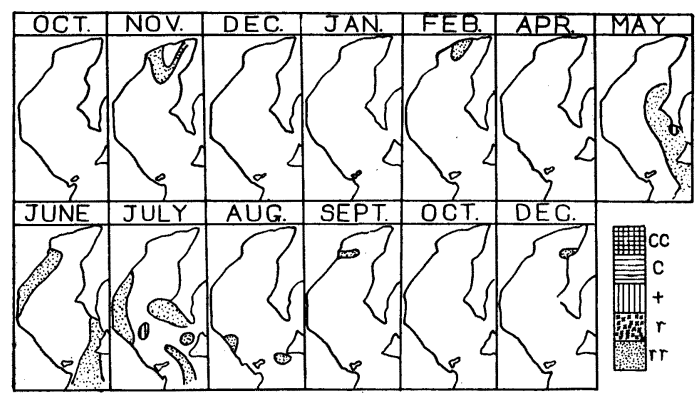

Fig. 9. Distributions of Gonyaulux polygramma in Ise Bay from Oct., 1950 to Dec., 1951.

して Skeletonema costatnm, Thalassionema nitzschioides (Fig. 7) が同傾向を示し, これら は伊勢湾のように極度に低かんとなる内湾では湾 奥には少なく，むしろ外洋水の侵入する秋から冬 にかけて全域にわたつて多量に出現する。

また夏季を中心として湾奥に出現するものとし $\tau$ Bacteriastrum varians (Fig. 8), Chaetoceros diversus がある。

周年出現するが極端な低かん種と考えられるも のに Gonyaulux polygramma (Fig. 9) があり,
5〜 7 月の低かん期には湾西部，拈よび三河湾海 域に分布する。Chaetoceros socialis は冬に出現 する内湾種で，15 16 Cl\%o が好適と思われ， 4 〜10月にはあまり低かんなところでは全然出現 していない。また，はなはだしい冷水性内湾種と してCh. subsecundus が 10〜12 月の湾奥にみ られ，5〜9月の高温期には全く見当らない。こ れは $10 \sim 15^{\circ} \mathrm{C}$ が好適水温と思われる。本群の出 現種をまとめると Table 1-(3) のようになる。

\section{4. 動物プランクトン}

1951 年 $5 ， 6$ 月の 資料が欠けているため，こ の季の状況を知り得ないが，前述のように高かん 期にあつても, 他の内湾に比べて著しく低かんな 本湾では, 適応性の弱い外洋種は全く散発的にし か見出されず，まとまつた分布を形成するものは ほとんどない。動物プランクトンの主体となつて いるものは, 適応性のはなはだ広い純内湾種と, 沿岸底棲生物の幼生である。主要出現種を Table 2 に示した。

本湾にみられる最子外洋性のものとしては Eucalanus cornutus, Sagitta enflata (Fig. 10) があるが，これは高かんとなつた 1951 年 10〜12 月だけにみられ，湾奥まで達している。さらに内 湾性外洋種としては Corycaeus speciosus があ り，一般に東部沿岸から知多半島にかけて外洋水 侵入水帯に周年分布し，10 月は高かんとなるた め湾全体に分布している。同傾向を示すものに Oncaea venusta があり，これは 4〜 7月の低か 几期以外は外洋水侵入路に主にみらうれている。 Oikopleura dioica (Fig. 11) は高かんとなる秋 に特に多く，その他の季節も $1 ， 2$ 月を除き外洋 水侵入路の縁辺にみられる。また Sticholonche zanclea す秋だけにみられ 10 月には全域に広が り極大を示す。

さらに,幾分内湾性の強い種としては, Evadne nordmanii, Penilia schamackeri があり, 前者 は 7 月の最低かん期, 10 月の高かん期の 外洋水 侵入水路にはみられず, $16 \mathrm{Cl} \%$ 前後が好適域と 考兄られ，後者は幾分塩素量域の幅広く，7月に は湾奥に分布がみられる。

つぎに内湾的性格強く, 周年出現する種として 
Table 2. Dominant Zooplankton Species in Ise Bay from Oct., 1950 to Dec., 1951.

\begin{tabular}{|c|c|c|c|}
\hline $\begin{array}{l}\text { Group } \\
\text { No. }\end{array}$ & $\begin{array}{l}\text { Occurred over the } \\
\text { entire periods. }\end{array}$ & $\begin{array}{l}\text { Occurred in special } \\
\text { restricted seasons. }\end{array}$ & The species which has special type of distr. \\
\hline 1) & & $\begin{array}{l}\text { Sagitta en flata } \\
\text { (Oct.-Dec.) }\end{array}$ & \multirow{3}{*}{$\begin{array}{l}\text { Temora discaudata } \\
\quad \text { (in winter at innermost part) } \\
\text { Gastropoda larva } \\
\quad \text { (in warm seasons, at innermost part) } \\
\text { Cirripedia larva } \\
\quad \text { (in warm seasons, at innermost part and } \\
\text { entrance) } \\
\text { Bivalve larva } \\
\quad \text { (over the entire periods, western coast) } \\
\text { Noctiluca scintillans* } \\
\quad \text { (near large current rips) }\end{array}$} \\
\hline 2) & $\begin{array}{l}\text { Oncaea venusta } \\
\text { Corycaeus speciosus } \\
\text { Oikoplera dioica* }\end{array}$ & $\begin{array}{l}\text { Stichlonche zanclea } \\
\text { (autumn) }\end{array}$ & \\
\hline 3) & $\begin{array}{l}\text { Favella ehrenbergii } \\
\text { Tintinnopsis fracta } \\
\text { T. mortensenii } \\
\text { Sagitta delicata } \\
\text { Evadne tergestina* } \\
\text { Penilia schmackeri* } \\
\text { Paracalanus parvus* } \\
\text { Acartia lonfiremis } \\
\text { Microsetella norvegica } \\
\text { Oithona nana }\end{array}$ & $\begin{array}{l}\text { Codonellopsis globosa } \\
\quad \text { (Oct.-Dec.) } \\
\text { Podon leuckartii } \\
\quad \text { (autumn) }\end{array}$ & \\
\hline
\end{tabular}

Group number 1): The species occurred in relatively haline region. 2): The species Occurred near the border between neritic and invaded waters. 3): The species occurred in the innermost part of the bay. *: absent in winter.

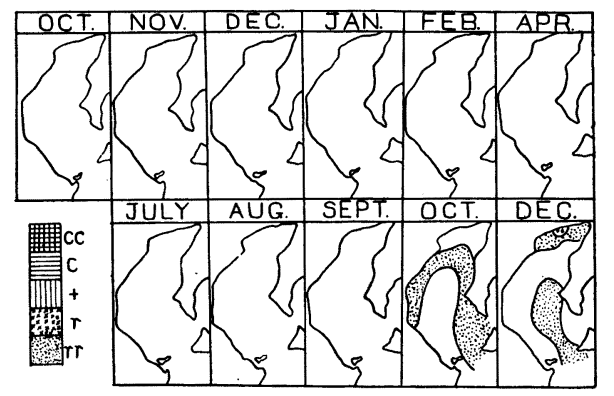

Fig. 10. Distributions of Sagitta enflata in Ise Bay from Oct., 1950 to Dec., 1951.

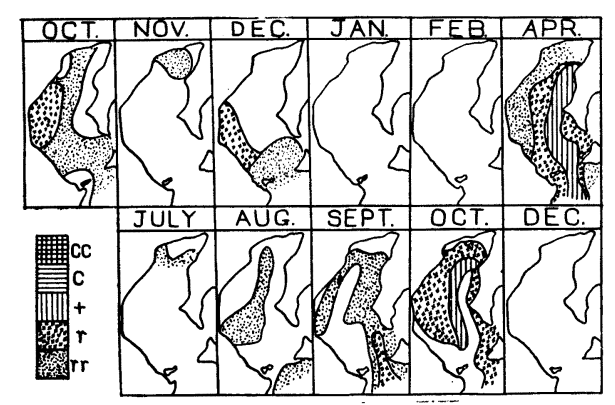

Fig. 11. Distributions of Oikopleura dioica in Ise Bay from Oct., 1950 to Dec. 1951.

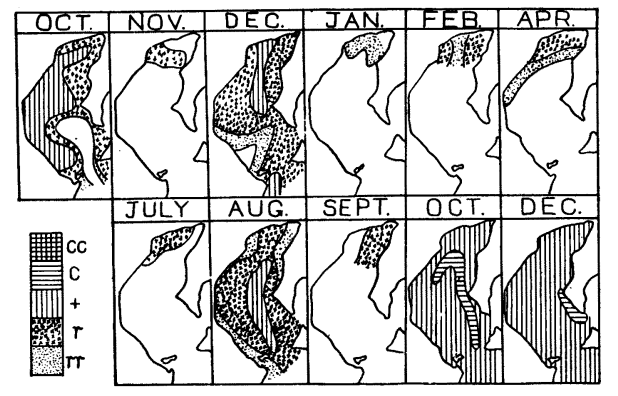

Fig. 12. Distributions of Microsetella norvegica in Ise Bay from Oct., 1950 to Dec., 1951.

は Tintinnopsis fracta, T. mortenseni, Acartia longiremis, Microsetella norvegica (Fig. 12), Paracalanus parvus, Oithona nana があ り, 前 2 者は最も内湾的傾向が強く湾 奥に出現 し, 後 5 者は西部沿岸には出現少なく, 中央の外 洋水々河川流入水との境界線に帯状に長く分布す ることが多く，秋に多くみられる。周年ではない が前 2 者と同傾向を示す海況に現われるものは, Codonellopsis globosa, Favella ehrenbergii, Saegitta delicata 等があり, 打もに秋季湾奥か ら西部にかけて分布がみられる。 
変わつた出現傾向を示す種としては, Temora discaudata が $1 \sim 3$ 月にかけての低温期に湾奥 に出現している。また Bivalva larvae, Gastropoda larvae も相当みられ，4〜8月は主として 湾口付近から知多半島よりに外洋水侵入水路にみ られ，8〜12 月は Gastropoda larvae は消失す るが, Bivalva larvae の方は別のものが低かん な西部沿岸に多くみられる。それと反対の傾向を 示すものに Balanus nauplius があり, $4 \sim 9$ 月には湾奥に, $8 \sim 12$ 月の高かん期には外洋水 侵入水路に出現している。

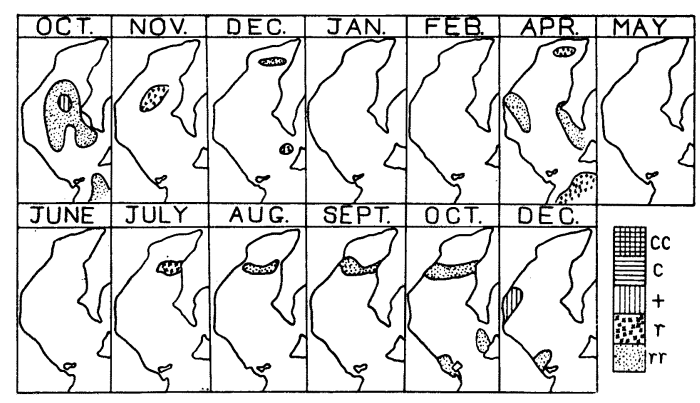

Fig. 13. Distributions of Noctiluca scintillans in Ise Bay from Oct., 1950 to Dec., 1951.

Noctiluca scintillans（Fig. 13）は春秋を通 じ, 湾中央部に分布が多く, 特に外洋水の強い 1951 年 8〜11 月は日長一四日市を結ぶ線上に帯 状になつて現われている。

\section{5. 総括一一海況との関連について}

以上を総合してみると, 動物, 植物プランクト ンとも内湾性のものが主として出現しているが, 三大河川の大流入水量に応じて低かん域が広範囲 を占めるため, 内湾性の強弱に応じて分布が分れ ている。したがつて流入河川水量の季節変動に応 じてプランクトン分布も変動することになる。こ とに珪藻の場合は塩素量分布に対する依存性が強 いため(上野，19574)，19585) この関係は密接で ある。大阪湾 (上野, 1957)出の場合は本湾に比べ て流入河川水量が少ないため, 著しい低かん域が 広がるのは梅雨期だけであつたが，本湾ではしば しばである。Fig. 1 に示した塩素量分布によれ ば，外洋水侵入の指標としている $17 \mathrm{Cl} \%$ 線が湾 奥付近にまで達するのは 10 月より翌年 $2 \sim 3$ 月
までで，その他の月は括括むね湾口付近にあつて 湾全域が河川流入水の影響下にあると考兄られ る。特に塩素量低下の激しい 6,7 月には湾奥付 近では $10 \mathrm{Cl} \%$ 以下となり, 湾内中央部以北では 低かんによる珠藻量の著しい隇少がおこつてい る。このような現実は低かん期には常に湾奥から 西部にかけて発見される。したがつて低かん期の 珪藻濃密部は概して東部の外洋水侵入水路付近に 現われ, 河川流入水影響部には特定の極く内湾性 の強いものしか現われない。このため珪藻の増殖 の最も盛んなときは, 梅雨による大量の流入河川 水が停止し, かつ水温の高い $8 \sim 9$ 月と, $17 \mathrm{Cl}$ $\% o$ 前後の塩素量值が 全域にわたつて分布する 11 〜12 月にみられる。この場合の 分布域は内湾性 の強い種が湾奥から西部にかけて分布し, 湾口か ら東部の外洋水侵水路には, これょり高かん性の 内湾種特よび外洋種がみられる。外洋種の出現は ほとえどこの期間に限られる。

Dinoflagellata の出現傾向は, 原則として上述 の珪藻の出現傾向と同梯と考えられるが, 汇とん ど大部分のものは 8〜12 月に出現する。この期間 は高かん期であるが，かならずしも高かん期に出 現するとは考えられず，秋季に限つて出現する制 約要因は何か他にあるものと考えられる。Dinoflagellata が秋季に出現することは古くから一般 にいわれて拉り, 大阪湾 (神戸海洋気象台海洋課, 1951)6)の場合も同様である。

動物プランクトンは, 一般に, 内湾種は特に棲 息環境域が広く, 外洋種は狭い。本湾のように著 しく低かんとなる内湾では外洋種の侵入は非常に 稀で，高かん期にたまたま散発的に侵入してくる 程度である。出現種のほとんどすべてが内湾種 で, 特に Palacalanus parvus, Evadne nordmanii, Penilia schmackeri, Microsetella norvegica, Oithona nana の 5 種が卓越している。 しかしながらこれらの内湾種も低かん期には外洋 水侵入水路付近に分布の中心があり, 北部, 西部 の低かん域には減少している。

以上のほか，本湾の動物プランクトンには幼体 が非常に多い。これは当然その親の産卵時期と棲 息場所によつて制約されるのでまちまちである が，特に多いのは Gastropoda, Bivalva および 
Balanus の幼生である。また Noctiluca scintillans は表層流に支配されるため常に流入河川水 の縁辺である $15 \mathrm{Cl} \%$ 付近に出現する塩素量水平 傾度の急な部分に局所的に出現している。

\section{5. 要 約}

本報は伊勢湾に打ける 1950 年 10 月より 1951 年 12 月に至るプランクトンの季節変動と海況と を対比させて，その相互関係を明らかにした。伊 勢湾は流入河川水の影響を受けた低かん水が湾奥 から西部沿岸沿いに南下し，一方湾口からの高か ん外洋水の侵入は東岸沿いに北上する。これらの 消長は表層の塩素量水平分布に明確に現われる。 すなわち各月とも $15 \mathrm{Cl} \%, 17 \mathrm{Cl} \%$ の両等塩素 量線付近の水平傾度が急で, これがそれぞれ流入 水怙よび侵入水の縁端であることを示す。両勢力 の季節的消長は, これらの等塩素量線の位置とな つて現われ，梅雨を中心とする低かん期には湾口 付近に，10〜12 月の最かん期には湾奥に位置す る。したがつて植物プランクトン分布もこれと対 応し, 各種の濃密部が $17 \mathrm{Cl} \%$ 以上, $15 \sim 17 \mathrm{Cl}$ \%，15 Cl\%以下の 3 区に分れて出現する。これ に季節的特徽を加味すると, (1)「外洋性群」(2)「高 かん性内湾種群」(3「低かん性内湾種群」となる。
これらの 3 群は, それぞれ塩素量に対する適応值 の高低を示している。な拈一部の狭温種は水温の 水平分布の影響も含まれる。

一方, 動物プランクトンは湾内が著しく低かん となることがあるため, 広塩性の純内湾種と沿岸 底棲生物の幼生が周年主体を占め, 外洋種は 10 〜12 月の最高かん期に限り全く散発的に見出さ れるのみである。

\section{文献}

1）海洋気象台: 伊勢湾, 三河湾海洋観測報告, 海 洋時報, $5: 1-1 \sim 66,1933$.

2) 三重県水産試験場伊勢湾分場：昭和 25 年度事業 報告沶よび昭和 26 年度事業報告, 1950, 1951.

3）上野福三：日本近海に㧊㣌る主要珠藻の量特性 と增殖期について一主としてプランクトン時報 資料の解析， Rep. Fac. Fish., Pref. Univ. Mie, 3 : 2-407 435, (1959).

4) ——: 夏季の大阪湾に括ける珠藻群集の遷 移々增殖の模式的表現 (第 $1 \sim 3$ 報), 日本海洋 学会誌, 13:73〜84, 107〜110, (1957).

5) : : 本州南岸付近の珠藻量と海況々の関 係, 主として重要種の水温执よび塩素量に対する 一般的特性について, 海と空, 34:4-92 112, (1958).

6）神戸海洋気象台：浮游生物速報, 大阪湾定線定 期 [1]， (1951). 